\title{
CROSS BORDER POLLUTION - PRIVATE INTERNATIONAL LAW PROBLEMS IN CLAIMING COMPENSATION
}

\author{
Alexander Szakats*
}

In this paper the late Professor Szakats offers a review of the private international law aspects of the damage caused by the discharge, of poisonous waste from a gold extraction enterprise in Romania, into a river which flowed into the river Tisza and through Hungary.

It is fitting that this paper relates to Hungary and the much loved River Tisza - steeped in history and a source of inspiration to poet and patriot alike.

\author{
I stood there, silent, without stirring, \\ As if my feet were rooted to the spot, \\ My soul intoxicated by a sweet, profound ecstasy \\ Induced by nature's eternal beauty. \\ Oh nature, oh glorious nature! \\ What language would dare compete with you? \\ How splendid you are! The more you are silent, \\ The more you say, the more the beauty of your expression. \\ Sándor Petófi, The Tisza
}

\section{A SAD SAGA OF RIVER POISONING}

An enterprise in Baia Mare (Nagybánya, in Erdély, formerly part of Hungary) owned in equal shares by the Romanian Aurul SA (Aurul) and the Australian Esmeralda Explorations (Esmeralda) had been carrying on the business of gold extraction with a

* 1915-2001. Dr Iur Dr Pol (Budapest), LLB (NZ), Professor Emeritus of Law (Otago), Employment Law Adviser.

The author is grateful to Professor Ferenc Mádl, formerly Chairman, Institute of the Law of Conflicts and International Economic Relations, Eölvös Lörànd University, Budapest, President of the Hungarian Republic since August 2000, and to the many other jurists, diplomats and media persons who greatly assisted him by giving much information and advice. 
process involving the use of cyanide, a lethal poison. On 30 January 2000 the wall of the reservoir holding the waste collapsed and discharged its contents in the nearby Somes (Szamos) river which, as a tributary, carried the poison across the frontier into the river Tisza in Hungary. More than 100,000 cubic metres of cyanide, according to expert estimation, entered the rivers and killed fish and other aquatic creatures such as crabs, snails and micro-organisms. ${ }^{1}$

During the first days of the disaster it was estimated that over 200 tonnes of rotting fish was collected. This number was, with later findings, increased to a total of 1241 tonnes. Animals feeding on fish - otters, foxes, wild pigs - and a variety of birds also fell victim. ${ }^{2}$ Further spills of toxic pollutants from Romanian mines were also found to have entered the river system in Eastern Hungary. ${ }^{3}$ The January spill was compounded when a springtime flood caused a second spill - of 20,000 cubic metres of toxic sludge. ${ }^{4}$ Tests later showed copper, lead and zinc had been present in the spill, ${ }^{5}$ and Romanian officials claimed that the cyanide concentration was 7,800 mg per litre compared with an admissible level of $0.1 \mathrm{mg}$ per litre. ${ }^{6}$ Altogether 109 other potential contamination sources have been found to exist in Romania. These could also, at any time, release toxic waste.

1 "Cyanide leak heads towards Danube killing every living thing in its path; Death moves downstream" The Independent, London, 14 February 2000, 12; "Romania counts the cost of cyanide river disaster" Sunday Times, London, 20 February 2000. These are just two examples of the numerous press and electronic media reports on the event between 14 February and August 2000.

2 On 20 February 2000 The [Scottish] Sunday Herald reported that 100,000 tonnes of fish had been killed ("Nothing is Alive. Zero", 13), including some rare species, and that other wildlife had also died. Another article claimed that 80 percent of the fish in the Tisza had died ("Cyanide leak heads towards Danube killing every living thing in its path; Death moves downstream" The Independent London, 14 February 2000, 12). See also Magyar Nemzel (Hungarian journal), 8 July 2000 and 15 July 2000 .

3 Several news reports have outlined "waves" of pollution occurring after the 30 January incident: "Hungary: Three waves of heavy metal pollution caused by one break" BBC Monitoring Europe Economic, 16 March 2000; "Environment: On a wing and a prayer" The Guardian London, 12 July 2000, 9; "New wave of toxic spill reaches Hungary from Romania" AP Wordstream, 15 March 2000. The Sunday Times (London) also reported resident claims that the 30 January incident was the third in ten months ("Romania counts the cost of cyanide river disaster", 20 February 2000).

4 "Environment: On a wing and a prayer" The Guardian London, 12 July 2000, 9.

5 "Hungary: Three waves of heavy metal pollution caused by one break" BBC Monitoring Europe Economic, 16 March 2000; "New wave of toxic spill reaches Hungary from Romania" AP Wordstream, 15 March 2000.

6 "Cyanide leak heads towards Danube killing every living thing in its path; Death moves downstream" The Independent, London, 14 February 2000, 12. 
The cumulative effect of such spills, perhaps insignificant alone, had a considerable impact on the environment. The poisoned river water contaminated good agricultural land growing crops, vineyards and orchards. This caused more lasting detriment as the soil itself became penetrated with poisonous substances. ${ }^{7}$ The water, according to expert opinion, clears within a reasonably short time - indeed the Tisza is already nearly back to its pre-cyanide consistency - but traces of poison and heavy metal (such as copper, zinc and lead) embedded in the soil will take about 15 years to disappear.

The contamination of the foodchain and the destruction of life in the Tisza and in a substantial area around it, grievously harmed not only fish, animals and vegetation but also caused misery to about 2.5 million persons, that is about one-quarter of the country's residents. The foodchain, environment, leisure and economy were all affected; the use of the polluted water for drinking, fishing and swimming was prohibited, the few fish that remained alive in the Tisza and in other infected rivers and lakes were considered unfit for human consumption and fishermen, fish merchants, and restaurants lost livelihood. Formerly popular holiday resorts remained empty. The Tisza itself was mourned as dead. ${ }^{8}$

\section{THE AFTERMATH}

The Environment Protection Committee of the Hungarian Parliament, after examining reports of the damage, declared the contamination of the affected areas "the most serious environmental catastrophe since the Chernobyl nuclear leakage" and a matter for which the joint venture of the Romanian Aurul and the Australian Esmeralda should take responsibility. Some responsibility should, however, be borne by the Romanian state as owner of $49 \%$ of the shares in Aurul, and also the Romanian state for allowing unsafe working methods. ${ }^{9}$

Initially both Aurul and Esmeralda denied liability, as did the Romanian Government. ${ }^{10}$ They maintained that the spill was a minor accident, the consequence of which the Hungarians overstated. Brett Montgomery, chief executive of Esmeralda, was quoted by the Sunday Times of London as saying "These claims cause me considerable

7 Hungarian Consulate, Bulletin, Sydney, 9 and 28 February 2000. In parts of the country not affected by the cyanide poisoning fortunately the harvest was very good according to later information.

8 Magyar Nemzel, 8 July 2000. The Tisza joining the Danube carried cyanide causing similar damage down to the Black Sea.

9 Z Illés, chairman; Hungarian Consulate, Bulletin, Sydney, 15 February 2000.

10 Evening Post, Wellington, 15 February 2000. 
scepticism. It is most unlikely that given the volume of water and the distance travelled that the cyanide levels would be such to cause poisoning". ${ }^{11}$

The rest of the world, however, took a different view. Led by the Director of the Environment Protection Programme of the United Nations, 25 experts from 14 countries visited the damaged area, examined and measured the extent of the devastation. ${ }^{12}$

The European Union's Commissioner on Environment Defence ${ }^{13}$ held out the promise of financial assistance on favourable terms. The principal negotiator ${ }^{14}$ on Hungary's application for membership added that the European Union would consider measures to compensate for the damage, and emphasised that the cyanide pollution would not affect the membership application .

Whether or not as a result of international condemnation, the two companies and the Romanian Government began to show a more conciliatory attitude. The Romanian Prime Minister ordered an inquiry to find the cause of the spill, the Foreign Affairs Minister admitted that Hungary's claim had to be taken notice of, and the Minister of Environment proposed a joint committee for estimating the extent of the damage. The General Director of this Ministry admitted that the river's cyanide content was 700 times higher than usual and added: "I want to investigate whether any quick measures have been taken to minimise the harmful consequences". ${ }^{15}$

Esmeralda also made statements about assisting Hungary in clearing up the polluted waters, but always with strong emphasis that such help would be a matter of "good will" only without any admission of liability. In fact nothing was done. The process of gold extraction involving cyanide - they asserted - was absolutely safe, and the prohibition by the European Union on its use was absolutely irrelevant as the Romanian Government had been granted a licence for applying it which, though described as temporary, could be routinely renewed. ${ }^{16}$ The European Union forbids the use of cyanide, but Romania, not being a member, was free to use it.

11 "Romania counts the cost of cyanide river disaster" Sunday Times, London, 20 February 2000.

12 Hungarian Consulate, Bulletin, Sydney, 28 February 2000

13 Mrs Margo Wallström, Bulletin, Hungarian Consulate, 16 February 2000.

14 Giorgio Bonacci, MTI 28 February 2000.

15 Hungarian Consulate, Bulletin, Sydney, 15 March 2000, summarising press reports.

16 The Dominion, Wellington, 19 February 2000. 


\section{SEEKING COMPENSATION}

None of the conciliatory statements resulted in admission of liability and there was no agreement to pay compensation. Every pronouncement indicating a willingness to settle had many conditions and was for amounts representing less than one-tenth of reparation expenses. $^{17}$

Unfortunately no international treaty or convention on environmental protection regulates countries' duties to prevent harmful by-products of industrial waste and any noxious substance resulting from otherwise lawful activities to cause damage in neighbouring states. The Helsinki Convention of 1992 and the Sofia Treaty of 1994 would merely make a country liable for activities within its territory which could adversely affect a neighbour, and order that they must cooperate in this respect for protection and preservation of the environment.

Both documents are silent on liability for crossborder pollution, and only provide for the formation of a joint arbitrating body in case of disputes. The Sofia Treaty binds only countries containing a segment of the Danube. Romania did not ratify either of these international documents.

A committee of experts was formed in Hungary to advise the government on the best action to be taken on the pollution disaster.

A non-governmental grouping of the intelligentsia, the $\mathrm{MAG}^{18}$ stated its view as: ${ }^{19}$

[W]here in international law, conventions, international treaties there would seem to be a gap

in respect of our claim, and the rules of delictual liability based on fault for compensation would not be applicable, then Romania is responsible on the basis of no-fault strict liability.

Accordingly a state is under strict liability, if it allows on its territory the starting of an enterprise whose activities, though it does not belong to the sphere of neighbourhood's legal administration, causes damage by its dangerous penetration in neighbouring states.

This resolution was sent to the President of the Experts Committee, Dr Lászlo Sólyom, formerly President of the Constitutional Court, for action.

17 Magyar Nemzel, 5 June, 7 June and 15 July 2000; Hungarian Consulate, Bulletin, (Sydney, 15 July 2000); (MTI Hungarian Information Bureau, Hungary, 15 July 2000). L Burian, "A tiszai környezetszennyezéssel kapcsolatos károk megtéritèseröl", (On compensation for damages connected with environment pollution around the Tisza), unpublished paper.

18 Magyar Alktok és Gondolkozók Fùggetlen Szakértóì Társaság, (Hungarian Creators and Thinkers Independent Expert Society), a select private organisation of eminent jurists, scientists, writers and others.

19 Translated from Hungarian by the author. 
One learned jurist, Professor János Bruhács, while recognising the lack of any international agreement expressly providing penalties for cyanide pollution, affirmed the view that international treaties signed by the state of Romania and generally accepted conventions, constitute legal grounds for a compensation claim.

Various legal actions were contemplated:

(1) a public law claim by the Republic of Hungary against the Romanian state;

(2) a private law action against Romania in its capacity as holder of $49 \%$ of the shares in Aurul;

(3) a public law claim against Australia, either the Commonwealth or the particular State where Esmeralda was registered, or both;

(4) a private law action or actions against the same;

(5) a private law action against Aurul; or

(6) a private law action against Esmeralda.

Which of these actions could be regarded as promising the greatest possibility of success on strict legal grounds? Also necessary before the commencement of litigation which would be protracted and expensive - is a thorough examination of the various aspects of the applicable procedure and substantive law. Without this even a valid claim might fail.

\section{PUBLIC LAW ACTION}

The Hungarian state as a public law entity and sovereign state, may commence an action for recovery of damages against the state of Romania in the International Court of Justice at The Hague. This Court is the proper forum for adjudicating conflicts of a civil character between independent countries. However, there is no special treaty on interstate pollution, Romania did not ratify the two relevant treaties, and has the right not to recognise the International Court of Justice's jurisdiction.

An influential publicist, referring to the stance of the MAG, commented in Magyar Nemzel (a leading Hungarian daily paper) that there were serious objections about taking the claim to the International Court on the grounds that the International Court of Justice was not suitable for deciding conflicts of such great importance within a reasonably short time, and that in any event before commencing such an action lengthy diplomatic conciliatory negotiations are required.

Public law action before the International Court of Justice thus appears to have been ruled out. Bringing private law actions seems more realistic. 
When bringing action against a foreign tortfeasor many preliminary issues must be determined before the merit of the claim can be considered. The problem with rights arising from wrongful acts or omissions hurting plaintiffs in foreign countries is not a well-settled branch of the law. The different theories have been the subject of considerable controversy. The four main theories are: ${ }^{20}$

(1) Lex loci delicti (or lex loci commissi). The law of the place where the wrong was committed governs the rights of the plaintiff and the liability of the defendant.

(2) Lex loci obligationis. Recovery in one jurisdiction for a wrong committed in another must be upon the ground of an obligation incurred at the place of the wrong.

(3) Lex fori. The courts should deal with the tort as if it had occurred within their jurisdiction.

(4) Compromises between lex loci delicti and lex fori. ${ }^{21}$ An action based on a foreign tort can be maintained in the court where the action is brought, if the act complained of is a tort both in the place where it occurred and in the place where the action is brought.

In the Tisza case, was the tort committed in Romania or in Hungary? Where the wrongful act was done or where the damage happened? What is the cause of action?

At this point the observation of Goddard LJ should be borne in mind: ${ }^{22}$

the cause of action and the right of action ... are two different things ... [T] he cause of action is the wrongful act or default of the defendant. The right to bring the action depends on the happening of damage...

Du Parcq LJ in the same case said: ${ }^{23}$

[T] he question is: Where was the wrongful act, from which the damage flows, in fact done? The question is not where was the damage suffered, even though damage may be the gist of the action.

20 See C M Schmitthoff, The English Conflict of Laws 161 and following; B D Inglis Conflict of Laws (Sweet and Maxwell, Wellington, 1959) 473 and following.

21 See for instance the approaches in Chaplin v Boys [1971] AC 356.

22 Draper $v$ Trist and Tristbestos Brake Linings Ltd (1939) 56 RPC 429, 442, quoted in George Munro Ltd v American Cyanamid and Chemical Corpn [1944] 1 KB 432, 439.

23 Draper $v$ Trist and Tristbestos Brake Linings Ltd, above n 22, 441. 
The cause of action, it may be said, was the discharge of a poisonous substance in Romania, but the damage resulting from it occurred in Hungary. The two facts are links in the chain of causation; the discharge without the damage caused would have no relevance. The spill became a tort only by the damage caused. The spill with the consequent damage together constitutes the tort which is not complete until the last event has happened. ${ }^{24}$ Where was the tort committed, where is the locus commissi? There is no logical reason why a tort cannot be committed in several jurisdictions.

The difficulty in deciding whether the cause of action is the initial conduct of the wrongdoer or the harmful consequences flowing from it, and whether the act or omissions will be actionable at the place of the defendant or of the plaintiff was addressed in an Australian case. ${ }^{25}$ The answer was a compromise solution: the act or omission by the defendant can be actionable as a tort at the suit of the plaintiff both by the law of the place where the wrong was done and by the law of the place where the consequences manifested themselves.

In finding the cause of action the important fact is not the defendant's wrongdoing but that the wrongdoing caused damage for which the defendant can recover compensation. ${ }^{26}$

Hungarian private international law does not substantially differ from the theories and practice in Common Law jurisdictions. In the 19th century and in the first part of the 20th century Hungarian law was customary law developed by decisions of the highest appeal court, called the Curia, and writings of outstanding academic jurists. ${ }^{27}$ Since 1979 the legal norms have been codified. ${ }^{28}$ The principles based on customary law were mostly preserved. In the view of Professor Kecskés: ${ }^{29}$

The [codification] committee had to preserve the values ... and consider experience gathered in Hungary and abroad ... the merits and inferences drawn from the international conventions concluded by Hungary, while endeavouring to meet the demands of life, ... the clarity of economic drafting in the structure and lucidity in the text.

24 Restatement of the Law of Conflicts (American Law Institute, 1934).

25 Koop v Bebb (1951) 84 CLR 629.

26 Phillips $v$ Eyre (1870) 6 QB 1; The Mary Moxham (1876) 1 PD 107; Jones v Chatfield [1993] 1 NZLR 617 (HC).

27 Such as Mihaly Szantó, R Dell'Adamis, E Willmann, István Szászy, Ferenc Mádl, L Reczei, M Villághy.

28 Law Decree No 11, 1979, Code of Private International Law (referred to as "the Code PIL").

29 L Kecskés "Private International Law" in Introduction to Hungarian Law (Kluwer, 1998) 167, 169. 
The Code of Private International Law in its introductory provisions contains regulations on the general institutions of private international law, the priority of international treaties over the conflict of laws of the country, characterisation, renvoi, reciprocity, non-application of foreign law, jurisdiction, procedure, recognition and enforcement of foreign judgments. ${ }^{30}$

The substantive rules of foreign law directly relating to the issue will be applicable. If the foreign law refers to Hungarian law, renvoi is accepted. ${ }^{31}$ Foreign law should be ascertained by expert opinion or the Minister of Justice's information on request. If foreign law cannot be ascertained Hungarian law will be applied. ${ }^{32}$ Application of foreign law does not depend on reciprocity, ${ }^{33}$ but if it would violate Hungarian public policy it must not be applied.

Differences in the social and economic system of a foreign country from that of Hungary is, in itself, not a sufficient ground for not applying the law of that country. ${ }^{34} \mathrm{~A}$ foreign law, nevertheless, emanating from a foreign element introduced by the parties artificially or by simulation with the intention to circumvent the legal rule otherwise applicable shall not apply. This is called a fraudulent connection. In such a case the law otherwise applicable by virtue of the provisions of the Code shall apply. ${ }^{35}$ If the parties agree to request the non-application of the foreign law which would be applicable according to the Code, then Hungarian law, or if the parties have the right of choice, the law chosen shall apply. ${ }^{36}$

The law prevailing at the place and time of the injurious act or omission shall apply to liability arising from non-contractual wrongdoing; this is the same as the lex loci delicti approach.. If, however, it is more favourable for the plaintiff suffering the consequences of the defendant's injurious conduct, then the law of the state where the damaging effects materialised shall govern. ${ }^{37}$

\footnotetext{
30 The Code PIL ss1-9.

31 The Code PIL, s 4.

32 The Code PIL, s 5.

33 The Code PIL, s 6.

34 The Code PIL, s 7.

35 The Code PIL, s 8.

36 The Code PIL, s 9.

37 The Code PIL, s 32.
} 
Where, under the law of the country where the conduct causing the damage occurred, liability depends upon the existence and proof of fault, the capacity to act in a way attracting liability may be determined either according to the personal law of the defendant, or according to the country where the damage flowing from the wrongful conduct damaged the plaintiff. ${ }^{38}$

A Hungarian court shall not find liability for conduct not unlawful under Hungarian law. ${ }^{39}$

In Romania the statute on private international law ${ }^{40}$ provides that in cases of extracontractual liability the law of the state where the damaging act or omission occurred should govern, though there is possibility of applying the law of the place where the damage eventuated. ${ }^{41}$ Capacity to be held responsible criminally or committing a civil wrong should be judged by the law of the state where the conduct causing damage occurred. The type and extent of responsibility is to be determined by the same law. ${ }^{42}$ The Act allows the application of the law of the place where the damage happened, but Romanian courts mostly apply the lex fori.

\section{JURISDICTION}

Accepting the view of the compromise theory that an action based on foreign tort can be maintained in the court where the action is brought, provided that the wrong complained of is an actionable tort in both countries, and Esmeralda was sued in Australia, the presence of the defendant is likely to found jurisdiction but on the facts exercise may be declined on the basis of a forum non conveniens plea. Once seized of the case an Australian court would possibly now apply the lex loci delicti as the substantive law. ${ }^{43}$

A favourable final judgment could immediately be executed against all assets of the company in Australia. However, Esmeralda has gone into liquidation so the possibility of a successful outcome is largely academic. The Hungarian Government presented its

\footnotetext{
38 The Code PIL, s 33.

39 The Code PIL, s 34.

40 Statute No 105, 1992.

41 Statute No 105, s 108

42 Statute No 105, s 107 and following.

43 John Pfeiffer Pty Ltd v Rogerson (2000) 172 ALR 625.
} 
claim for 29.37 billion forints (US\$108 million). ${ }^{44}$ The compensation sought covered costs incurred by the pollution, including:

(1) removing and destroying 1241 tonnes of dead fish;

(2) clean-up operations; and

(3) long-term damage.

If Esmeralda were sued in a Hungarian court questions could also arise as to whether a judgment could be executed in Australia. This problem will not ever be an actual one, because the Hungarian Government has already elected to sue in an Australian jurisdiction.

The claim against Aurul could be brought in a Romanian court which would have jurisdiction because the Romanian statute on private international law specifically gives primary jurisdiction to the state where the damaging conduct occurred, in this case Romania. It is not expected that the court would prefer the second option in their Act the place where the damage materialised, Hungary.

Without denying the Romanian courts' judicial impartiality and fair dealing, the state of Hungary as plaintiff (sueing not in a public law capacity but in the name of the Treasury as a private litigant) may hesitate to bring an action there, being anxious to avoid any political undercurrents. Individual Hungarian citizens seeking compensation may have the same anxiety. The Romanian courts themselves - in some senses - may prefer not having to deal with these "delicate" matters. ${ }^{45}$

Hungarian courts certainly have jurisdiction. If it is more favourable to them, the injured person may select the jurisdiction and law of the place where the damaging effects materialised, in this case Hungary. ${ }^{46}$ Applying Hungarian law, the court will decide on the basis of the defendant's strict liability, thus only the happening of the damaging event and the causal link with the defendant's conduct must be proved, but not any fault. The difficulty of this otherwise correct choice of forum lies in its impracticability: there are doubts whether Romanian courts would recognise and execute Hungarian judgments.

44 MTI, 10 July 2000; BBC News, 10 July 2000.

45 See Burian, above n 17; Governor of Pitcairn etc $v$ Sutton [1995] 1 NZLR 426 (CA).

46 See Code PIL above n 31; individual Hungarian citizens who had suffered damage commenced actions at Hungarian courts. 


\section{CHOICE OF LAW}

Whichever court accepts jurisdiction it may apply the local law, if the wrongful act or omission equally is an actionable tort there, or elect to decide the suit on the basis of the law applicable in the plaintiff's country. Thus, in a suit brought against Esmeralda an Australian court may apply domestic law,${ }^{47}$ on environmental devastation, or apply the law of the plaintiff, Hungarian law.

There is no necessity here to analyse further Australian law, which is derived from the British Common Law.

Romanian and Hungarian law, on the other hand, need a more detailed analysis, as they show marked differences.

\section{A Romanian Law - Proof of Fault}

The Romanian Civil Code ${ }^{48}$ extends the general rules of indemnification to acts of environmental pollution, but demands proof of fault, negligence, carelessness, remissness of the defendant as a precondition to the finding liability.

The Romanian civil law is largely based on the French Code Civil, and French court judgments as well as opinions of outstanding academic jurists are frequently looked at by Romanian judges when confronted with an intricate problem.

The damage caused in the Tisza case is primarily material damage. For a lay observer it would seem clearly so. A Romanian court, nevertheless, would question and demand proof on these very points: did the plaintiff suffer material damage? If the damage suffered by the plaintiff is proved, did the defendant's conduct, fault, or negligence cause it? The plaintiff must prove that destruction of property and any injury which resulted from the defendant's fault caused a material loss measurable in terms of money. ${ }^{49}$

Further, the plaintiff may assert moral damage by suffering, mental and physical, caused by the restrictions imposed on the population as a consequence of being deprived of using the polluted waters and of all connected inconveniences; it may also include invasion of the state's sovereignty, a kind of invasion of privacy: Invasion of privacy actually suffered by about two and a half million individuals. This kind of damage cannot be measured in money, but the court may award an amount in addition to the compensation for physical damage.

47 Assuming the Chaplin $v$ Boys line of authority is used for international torts rather than the interstate rule of Pfeiffer.

48 Codul Civil, ss 998-1006.

49 Burian, above $\mathrm{n} 17$. 
When damage has been proved, further proof is required to show that there is a clear causal link between the defendant's act or omission and the damage caused to the plaintiff. In other words that the defendant's conduct led to the damage, the destruction was the direct consequence of it, and the defendant was responsible for it. Even though it is proved that the defendant was negligent or committed a fault, if the causal link between the wrongful conduct and the damage is not clearly shown, there will be no liability.

Causal relation in itself has always been a much debated factor. How far can preceding inter-locking events be taken into consideration as being relevant for causing the damage complained of? All the innumerable events antecedent to the damage cannot be regarded as the cause from the point of view of responsibility. Only those antecedent events which in the normal course of things are likely to produce the damage may be considered "the cause". The "adequate" cause is "the cause" which will normally produce the damage.

Romanian courts, following the practice of French courts approach the problem in an empirical way. ${ }^{50}$ They look at the logical connection but appreciate that the causes of events are usually complex; they pose the question: what was the effective cause? Though the question of fault is logically independent of the causal relationship, the courts try to answer the question: which among the several causes of the accident was the most blameworthy? They always emphasise, however, that the cause must be direct and certain.

Where the causal relationship is uncertain and not proved, the plaintiff's claim will be dismissed. Similarly, if the damage is indirect. In practice the courts proceed in a commonsense way, reject the remote and improbable and select the proximate and probable.

\section{B Hungarian Law - Strict Liability}

Before World War II Hungarian private law was customary law, based on longestablished unwritten principles, developed by judicial decisions, though certain specific areas were regulated by statute. "Unwritten" in this context means that the law was not laid down in statutory form passed by Parliament. Werboczy, ${ }^{51}$ prepared a compilation of the then existing statutes and customary law in Latin with the title Tripartitum. It was to be passed by the Parliament, but because of the Ottoman invasion it was never

50 Burian, above $\mathrm{n} 17$.

51 Isiván Werboczy, 1458-1542, jurist, highranking judge, politician, Palatinus (the highest ranking dignitary, second only to the king) for a short while, leading member of the lower nobility. 
formally enacted. In 1517, it was published and afterwards used as an authentic statement of law. Several later publications included developments recent at the time.

In the private law part Roman law principles strongly influenced the work which, despite not formally enacted, was regarded as a Code. In the 19th century, especially at the time of the dual monarchy, certain provisions of the Austrian Civil Code were on a customary basis accepted and used.

Private law was codified in $1959^{52}$ during the Communist era but the Code essentially preserved the customary law. With amendments eliminating "socialist" principles it has remained in force.

It is noteworthy that while general private law remained customary until 1959 business transactions were regulated as early as 1875 by the Commercial Code. This Code formulated distinct rules on commercial contracts, and its rules were often applied to non-commercial contracts too. After the enactment of and coming into operation of the Civil Code 1959, the Commercial Code was practically repealed as certain parts of it were included in the Civil Code. ${ }^{53}$

The Code primarily regulates contractual relations but devotes a substantial part to delictual liability. Its main distinguishing feature is the introduction of absolute, no-fault liability in cases of damage arising from the otherwise lawful activities of the so-called "dangerous enterprise". This concept developed in the second part of the 19th century with the railway transport industry. Later is was extended to motor vehicles, airlines, all mechanical transport, plants using and producing chemical substances, undertakings dangerous by their very nature, and of course, nuclear generation.

Section 345 of the Code provides:

(1) Anyone carrying on activity involving increased danger is duty bound to compensate from damage resulting therefrom. Exclusion or reduction of liability is null and void; this prohibition does not apply to damage caused to objects.

(2) The person shall be relieved from liability upon proof that the damage was caused by an unavoidable event beyond the scope of the extremely dangerous activity.

In simple words the mere fact that the plaintiff suffered an accident and injury is sufficient to make the "dangerous enterprise" liable, notwithstanding that its function remained within the normal course of usual lawful business. It is enough for the plaintiff

52 Civil Code 1959; Act No IV 1959 with amendments.

53 A Harmathy "Contracts and Torts", in Introduction to Hungarian Law (Kluwer, The Hague, 1998) 95120,97 
to prove that the damage occurred in consequence of using the services provided by the defendant; but the defendant will be exonerated on counterproof of an extraneous cause.

The general rule of liability for extra-contractual damages caused are laid down as follows:

Section 339(1). Whoever causes damage unlawfully to another, is duty bound to compensate

for it. He will be relieved of liability upon proof that he conducted himself in the manner as in

the given situation was generally to be expected.

This wording suggests liability based on fault with reversed onus of proof. Although in the opinion of influential jurists this rule is not based on fault, 54 "court decisions seem to consider it as the formulation of the rule of liability based on fault, a parallel one to the rule on strict liability and to other special rules on liability". The practice developed that section 339 could be applied in a subsidiary way in causes covered by other rules of delictual liability. Thus, a claim for damages may be enforced under the general rule of section 339 , as the limitation period is longer than under section $345 .{ }^{55}$

Harm deriving from activities of recent scientific and technological developments are regulated by special rules: nuclear energy, ${ }^{56}$ licenced medicaments, ${ }^{57}$ and most importantly damage caused to the environment by the Protection of the Environment Act. ${ }^{58}$

An amendment to the Code in 1977 enhanced the protection of persons and personality by inserting a rule that in case of serious injuries and violation of personal rights the court can order payment for damages not measurable in fixed amounts of money. Since 1990 courts have ordered payment for non-pecuniary damages more frequently. This is like moral damages in French law. In the opinion of a learned Hungarian jurist: ${ }^{59}$

The formulation of the rules of liability [in the Code] is so general that cases can only be decided on the basis of a careful analysis of previous court decisions. These are of great relevance not only from the point of view of law, as the limits to free action are set in this way,

54 A Harmathy, Lontai, Mádl, Kécskés and others.

55 A Harmathy, above $n$ 54, 115 and following.

56 Act CXVI, 1996.

57 Act II, 1972.

58 Act III, 1996

59 A Harmathy, above n 54, 117. 
but at the same time the way of reaction by means of delictual liability can be characteristic of the state.

Court practice has a specially decisive importance in interpreting claims on strict liability. The Code contains no definition on "activity involving increased danger" and "unavoidable event", the court has to decide in every individual case on analysing the facts and the actual activity. In this respect Hungarian private law may be compared to the common law as developed in England.

\section{PROBABLE DEFENCE}

Whether the applicable law applied demands proof of fault or strict liability for the declaration the joint venture of Aurul and Esmeralda to be a dangerous enterprise, the defendant may prove that the damage complained of did not arise from the normal operation of the enterprise but from an unavoidable event not connected with the normal business-like functioning of its activities; it was beyond human control.

In this respect the difference between negligence and absolute liability disappears. When proof of negligence is required the defendant, when denying liability, may assert that the damage resulted from a freak accident against which no reasonable precautions could have been taken, an act of God (as it is called in the Common Law), a vis major or force majeur (in civil law systems), an event that happens independently of human intervention due to natural causes, such as a storm, flood or earthquake. If the event happened in circumstances against which no human foresight could provide, and human prudence is not bound to recognise its possibility, there will be no liability. ${ }^{60}$

The onus of proof is shifted to the defendant. If the defendant is successful both alleged negligence and absolute liability will be rejected. In the Tisza case the defendants will strenuously assert that the collapse of the reservoir's walls and the subsequent entry of cyanide waste into the river was caused by unusually heavy rains and unprecedented snowfalls. Such vagaries of nature cannot be controlled and prevented by human prudence.

This assertion certainly seems a good defence, effective counterproof against fault and relieving the defendant from the burden of strict liability. The plaintiff, however, can question the facts, the essence of the defence. Was the rain and the snowfall really so heavy, so unprecedented? Could not prudence, common sense and human foresight have prevented the damage?

60 D M Walker, The Oxford Companion of Law (Clarendon, Oxford, 1980) 14; Hungarian Civil Code, s 345 (2). 
Could and should a stronger dam have been constructed knowing the hazards of the climate, the regularity of the "unusually" heavy rains and snowfalls? As they knew or should have known the poisonous effects of cyanide, should they have not used a less dangerous method? Considering all the circumstances it seems provable that lack of foresight-negligence - caused the "accident" which with proper care and workmanship could and should have been prevented.

It will be a question of fact, a matter of proof. Meteorologists' evidence may be called by both parties on whether or not the alleged unprecedented heavy rain and snowfall had never happened in that area, and whether or not with prudent human foresight by constructing a more solid, stronger reservoir it could have held the waste. Further, a most important point: was it necessary to use cyanide?

\section{ENFORCEMENT OF JUDGMENTS}

After a court pronounces judgment and if it orders the defendant to pay compensation, the plaintiff will not have succeeded in "winning" until he receives payment. Frequently the defendant does not want to or cannot pay. A judgment that is not obeyed is no use to the plaintiff. If the defendant has assets in the country where the court made the decision, the judgment may be enforced in the usual manner.

The difficulty arises when the defendant resides and has assets in another country. English courts recognise and enforce foreign judgments, provided they order payment of a definite sum, by instituting an English action upon the foreign judgment in order to obtain a "judgment upon a judgment". 61

Professor Gutteridge observed that: ${ }^{62}$

[i]n the great majority of cases the result is that the foreign judgment creditor obtains an English judgment within a very brief space of time and at a very small cost.

An Australian court most probably will follow the same procedure in case of a Hungarian or Romanian judgment, unless a treaty with Australia provides otherwise.

As far as recognition and enforcement of Hungarian judgments by Romania is concerned it entirely depends whether or not there is a treaty between the two countries providing for mutual recognition of judgments.

61 Schmitthoff above n 21, 479; Kemp v Kemp [1996] 2 NZLR 454 (HC); Von Wyl v Engeler [1998] 3 NZLR 416 (CA).

62 H C Gutteridge, "Reciprocity in regard to Foreign Judgments" (1932) 13 BYBIL 49, 54; NZ Post Ltd v Leng [1999] 3 NZLR 219 (HC); Panavision International LP v Toeppen (1988) US App Lexis 7557 (DC). 


\section{POLLUTION - A WORLDWIDE PROBLEM}

Environmental pollution is not only a Hungarian problem. After many years of exploitation of the earth's natural resources and throwing away all waste, pollution menaces every country; the entire flora, fauna, air, soil, rivers, and oceans. In the present case the cyanide from the Tisza poisoned the lower parts of the Danube causing similar destruction of aquatic life down to its delta at the Black Sea.

Every day the media reports poisonous waste from chemical factories, oil from shipwrecks, and disfunctioning nuclear energy generating plants. All these pollute the air, soil, rivers, and the seas, killing or harming all living creatures. The gradual depletion of the ozone layer is also attributable to gases escaping from millions of motor vehicles and other human inventions. The rainforests and many of the wooded areas are disappearing which all add to the lessening of ozone, polluting the air.

Whether the marvellous scientific and technological progress can be blamed for the depletion of ozone layer and the general warming of the climate, the melting of icebergs and rising sea levels, or it happens without any human intervention, like the ice age and its retreat, is for the scientists to answer. It is, however, for politicians and leaders of nations to seriously consider the increasing damage to the environment and take serious and effective measures against it.

Countries may, and most of them do, introduce and enforce strict measures for protecting their environment, but they have no power to prevent any polluting material escaping from a neighbouring state. In landlocked European countries the frontier is an invisible line cutting through identical paddocks and indicated only by a post or boundary stone. Rivers flow through without hindrance carrying over polluting material in the water.

The threat of further destruction of the environment, poisoning future generations, should be regulated by international treaties with special emphasis on crossfrontier pollution placing liability on the offending state. Every country should be compelled to provide strong measures for preventing internal, and guarding against external, pollution. The formation of a supranational organisation similar to the International Labour Organisation, with power of making treaties and conventions for regulating environmental defence, and establishing a tribunal with a simple and speedy procedure to settle disputes on crossfrontier pollution, may hopefully, be a solution. 